AperTO - Archivio Istituzionale Open Access dell'Università di Torino

\title{
A MULTI-ANALYTICAL APPROACH FOR THE CHARACTERIZATION OF POWDERS COMING FROM POMPEII ARCHAEOLOGICAL SITE
}

\section{This is the author's manuscript}

Original Citation:

Availability:

This version is available http://hdl.handle.net/2318/86981

since 2016-01-09T18:01:24Z

Published version:

DOI:10.1007/s00216-011-5216-8

Terms of use:

Open Access

Anyone can freely access the full text of works made available as "Open Access". Works made available under a Creative Commons license can be used according to the terms and conditions of said license. Use of all other works requires consent of the right holder (author or publisher) if not exempted from copyright protection by the applicable law. 


\section{A MULTI-ANALYTICAL APPROACH FOR THE CHARACTERIZATION OF POWDERS COMING FROM POMPEII ARCHAEOLOGICAL SITE}

Carmen Canevali (*),

Department of Materials Science, University of Milano-Bicocca, Via Cozzi 53, 20125 Milan, Italy e-mail: carmen.canevali@unimib.it

telephone number: +39-02-64485121

fax number: +39-02-64485400

Paolo Gentile,

Department of Geological Sciences and Geotechnologies, University of Milano-Bicocca, Piazza della Scienza 4, 20126 Milan, Italy

Marco Orlandi,

Department of Environmental Sciences, University of Milano-Bicocca, Piazza della Scienza 1, 20126 Milan, Italy,

Francesca Modugno, Jeannette Jacqueline Lucejko, Maria Perla Colombini,

Department of Chemistry and Industrial Chemistry, University of Pisa, Via Risorgimento 35, Pisa, Italy

Laura Brambilla, Sara Goidanich,

Department of Chemistry, Material and Chemical Engineering "Giulio Natta", Politecnico di Milano, Via Mancinelli 7, 20131 Milan, Italy

Chiara Riedo, Oscar Chiantore,

Department of IPM Chemistry and NIS-Centre of Excellence, University of Turin, Via Pietro Giuria 7, 10125 Turin, Italy

Pietro Baraldi (*), Cecilia Baraldi, Maria Cristina Gamberini,

Department of Chemistry, University of Modena and Reggio Emilia, Via Campi 183, Modena, Italy e-mail: pietro.baraldi@unimore.it

telephone number: $+39-0592055087$

fax number: $+39-059373543$ 


\begin{abstract}
Nine black powders found in Pompeii houses in 3 different types of bronze vessels (cylindrical theca atramentaria, unguentaries and aryballoi) were characterized in order to assess a correspondence between the composition and the type of vessel and, possibly, to verify if these powders were inks or not. For the compositional characterization, a multi-analytical approach was adopted, which involved the use of scanning electron microscopy-energy dispersive X-ray (SEMEDX), Fourier-Transformed infrared (FTIR) spectroscopy, Raman, X-Ray diffraction (XRD), electron paramagnetic resonance (EPR) spectroscopies, thermogravimetric analysis (TGA), gas chromatography coupled with mass spectrometry (GC/MS) and pyrolysis GC/MS (Py-GC/MS). Powders contained in cylindrical theca atramentaria form a homogeneous group, and their organic and inorganic compositions suggest that they were writing inks, while powders contained in unguentaries and aryballoi could have had several different uses, including writing inks and cosmetics. Furthermore, the composition profile of the powders found in cylindrical cases shows that at 79 A.D. in Pompeii archaeological site carbon-based inks were still used for writing, and iron-gall inks had not been introduced yet.
\end{abstract}

KEYWORDS: SEM-EDX, FTIR, RAMAN, XRD, EPR, GC/MS.

\title{
INTRODUCTION
}

The extraordinary importance of Pompeii for the study of the Roman age is essentially due to the eruption of Mt. Vesuvius that destroyed it in 79 A.D. and to the excellent preservation state of the ruins.

Within the framework of a project on the chemical study of colours and balms in antiquity for the knowledge of technologies in cosmetics, painting and medicine, nine black powders contained in bronze vessels found in Pompeii houses were characterized. The chemical knowledge of the composition of these powders could in fact reveal precious information relative to their use, to the degree of technological development of Roman society, and also could allow to choose the right conservation procedure in view of their musealization.

Of the nine powders examined, five were found inside bronze atramentaria (ink containers, Fig. 1a). According to archaeologists, atramentaria contain inks and can assume the shape of a cylinder when made of bronze, with a large hole for introducing both ink and a calamus (pen). The liquid overflow was dropped out by touching the border, where a small hole of about one $\mathrm{mm}$ in diameter enabled it 
to return into the vessel. The bronze containers also had a cover fitted to the hole, thereby avoiding evaporation of water when ink was not used and loss of liquids during journeys.

Four other black powders apparently identical to the powders found in atramentaria were found in other bronze containers, precisely two powders were found in unguentaries (Fig. 1b) and two in aryballoi (Fig. 1c). We included them in the present chemical characterization study in order to assess if they could have been writing inks or if they could have had other uses.

The contribution of analytical chemistry to cultural heritage grew significantly in the last 30 years with the development of techniques presenting features such as non-destructiveness and high resolution. Studying residues from archaeological findings is a complex field which poses a series of challenges for analytical chemistry [1]. This is due not only to the complexity of the chemical composition of the archaeological substances that may be present, but also to changes in their chemical composition, especially of the organic portion of the samples. These changes may be a consequence of human activities such as heating or mixing materials in order to modify their properties for a specific purpose, but also occur due to ageing. For all these reasons, the use of multi-analytical approaches providing complementary information, and enabling the (inorganic and organic) materials in the object to be reliably recognized, is thus particularly suitable for the chemical study of complex and degraded materials such as those from archaeological findings [2].

In order to assess the use of the examined powders, the results of the chemical characterization were compared to the receipts of inks used at Roman age. Lucas and Harris [3] reported that the black cakes found in some Egyptian palettes for writers were prepared with finely ground carbon and gum with water. From the first Egyptian dynasties to the eighteenth one only carbon was presumably used as a black ink.

Pliny and Dioskurides [4] also reported the formulas for the normal writing ink used by Roman scribes, which was prepared with soot and gum, probably mixed with water. Also an occasional use of vinegar was reported in the case of writing on papyrus.

Phylon of Bysance (III cent. B.C.) in "Veteres Mathematici" describes also an iron gall ink obtained from the oak galls and Roman vitriol, that is iron(II) sulphate. Phylon is probably one of Pliny the Elder sources [5], who reported the first appearances of an iron based ink, which was then used from the Medieval age up to $19^{\text {th }}$ century. Also Dioskurides reports a recipe of the ink made with carbon and iron compounds: half ounce of copperas (iron sulphate) and leather glue, and half pound of soot of burnt resin. He adds that this was also a good medicine against gangrene, when properly thickened.

Also Martianus Capella [6], at about 420 A. D. reports a formula of inks as "gallarum gummeosque commixtio" (a mixture of galls and gums). 
The transition from carbon based inks and iron gall inks was gradual, and for instance it is still doubtful if the Qumran rolls of the I century were written with iron gall ink [7].

McCrone et al. [8] analyzed some ink samples taken from the papyrus of the so-called Judas' Gospel. By transmission electron microscopy (TEM) images, the presence of soot was established, with a glue as a binder, compatible with the inks of the III and IV centuries B.C. Raman microscopy was also applied, and an iron gall fraction was identified, compatible with the inks used in the III century. Therefore the data reported testify that a traditional ink was based on carbon and a new ink entered into use about at the III century.

In this paper, nine black powders found in Pompeii houses in 3 different type of bronze vessels (cylindrical theca atramentaria, unguentaries and aryballoi) were characterized in order to assess a correspondence between the composition and the type of vessel and, possibly, to verify if these powders were inks or not. For the compositional characterization, a multi-analytical approach was adopted, which involved the use of non destructive or micro-destructive techniques as scanning electron microscopy-energy dispersive X-ray (SEM-EDX), Fourier-Transformed infrared (FTIR) spectroscopy, Raman, X-Ray diffraction (XRD), electron paramagnetic resonance (EPR) spectroscopies, thermogravimetric analysis (TGA), gas chromatography coupled with mass spectrometry (GC/MS) and pyrolysis GC/MS (Py-GC/MS).

\section{EXPERIMENTAL}

\section{Powders}

Nine black powders contained in bronze vessels were found in Pompeii houses (Table 1). Vessels were of three types: cylindrical theca atramentaria, unguentaries and aryballoi, indicated as type 1,2 and 3, respectively. Cylindrical cases have diameter of $2-3 \mathrm{~cm}$ and length of $4-5 \mathrm{~cm}$ (Fig. 1a), unguentaries (Fig. 1b) and aryballoi (Fig. 1c) have diameters of 4-5 cm.

\section{SEM-EDX analysis}

The SEM-EDX investigation was performed in high vacuum conditions by the scanning electron microscope Tescan Vega TS5136XM, equipped with an energy dispersion electronic microprobe EDAX Genesis 4000 XMS Imaging 60 SEM (accelerating voltage 20 kV, current 190 pA, working distance $23 \mathrm{~mm}$, spot size $250 \mathrm{~nm}$ ).

Before analysis, powders were lapped and polished in the following way. By a statistical sampling using the method of "rolling and division into quarters", for each powder a reduced but representative portion was obtained, which was placed on a glass slide, on which a thin layer (about 
$500 \mu \mathrm{m}$ thickness) of araldite (DBF resin, Huntsman, Everberg) has been previously deposited. Afterwards, the powder was covered by a thin layer of araldite (about $100 \mu \mathrm{m}$ thickness) and heated at $50{ }^{\circ} \mathrm{C}$ for 24 hours. The hard obtained sample was lapped with an Imptec 101 Grinder Polisher using abrasive papers with silicon carbide from 500 to 4000 mesh, then finely polished by using alumina powder of $1 \mu \mathrm{m}$ and $0.3 \mu \mathrm{m}$ and washed in isopropyl alcohol. At the end, samples were washed in distilled water and dried. The actual emergence of all incorporated grains and the quality of the lapping process were checked at the optical microscope, which showed the complete absence of lines on the surface of both the araldite and the powder granules.

Then, each lapped and polished sample was glued with araldite on cylindrical stubs $(25 \mathrm{~mm}$ diameter), obtained by homogeneously mixing 10 parts of araldite with 1.5 parts of hardener REN HY 956 (Huntsman, Everberg).

In order to assess the presence of carbon in powders, powders without any further treatment were investigated; then, analysis was repeated on samples deposited with graphite by an Agar Carbon Auto Coater.

At the EDX analysis, compounds have been identified by comparison of the elemental composition expressed as weight percent with databases (www.webmineral.com).

\section{FTIR characterization}

Infrared spectra of powders were recorded using a Thermo Electron Nicolet 6700 FTIR spectrometer. $\mathrm{KBr}$ pellets have been prepared in order to obtain spectra of samples in transmission mode, in the spectral range between 4000 and $400 \mathrm{~cm}^{-1}$, with $4 \mathrm{~cm}^{-1}$ resolution. Compounds have been recognized by comparison with spectra of pure minerals and/or databases (www.irug.org).

\section{Raman characterization}

The Raman spectra were recorded with a Labram instrument (Jobin Yvon-Horiba). The laser used had wavelength of $632.8 \mathrm{~nm}$, the Rayleigh radiation was eliminated with an edge filter and the Raman radiation was collected by a CCD $(254 \times 1024$ pixels $)$ cooled at $-70^{\circ} \mathrm{C}$. The spot to be analyzed was focused with the chosen objective Olympus 10x, 50x, 100x, and the laser, properly attenuated in order to avoid possible alteration of the material, was applied. The spectra were recorded in backscattering in several positions within a small area (down to about $2 \mu \mathrm{m} \times 2 \mu \mathrm{m}$ ) of the sample. The maximum power employed was $5 \mathrm{~mW}$ and the recording time for good signal-tonoise ratio varied between 10 and $100 \mathrm{~s}$, according to the intrinsic intensity of the radiation. Subsequently, GRAMS/AI 7.02 software was used for the elaboration of spectra. 


\section{XRD investigation}

X-Ray powder diffraction was performed using a Philips PW1830 X-Ray Diffractometer, with a PW3020 goniometer in the Bragg-Brentano geometry and a copper anticathode (Kal radiation). Samples were finely grinded and deposited on a proper sample holder in order to obtain a surface as smooth as possible. This technique was used to identify mineral phases present in the powders.

\section{EPR characterization}

The EPR spectra of powders were recorded at room temperature on a Bruker EMX spectrometer working at the X-band frequency. Spectra were acquired using a microwave power of $1 \mathrm{~mW}$, a modulation amplitude of $1.0 \mathrm{G}$, and a modulation frequency of $100.0 \mathrm{kHz}$. The $\mathrm{g}$ values were determined by standardization with $\alpha, \alpha^{\prime}$-diphenyl- $\beta$-picryl hydrazyl (DPPH, $g=2.0036 \pm 0.0003$ ). The concentrations of the paramagnetic species, expressed as number of spins per gram of sample ( $\mathrm{spin} / \mathrm{g})$, were evaluated by double integration of the resonance line areas (precision $\pm 10 \%$ ). The obtained area values were compared to that of the standard Bruker weak pitch, which contains $9.7 \times$ $10^{12} \pm 5 \% \mathrm{spin} / \mathrm{cm}$. Care was taken in order to obtain that the sensitive part of the EPR cavity $(1 \mathrm{~cm}$ length) was always filled; the weight of the sample filling $1 \mathrm{~cm}$ length of the EPR tube was always accurately determined.

\section{TGA analysis}

Thermogravimetric analyses were performed with thermogravimetric analyzer TGA 2050 (TA Instrument). About 8 to $10 \mathrm{mg}$ of material were loaded in alumina pan and introduced in the microfurnace. Analyses were done in dry air and the temperature program was from $40^{\circ} \mathrm{C}$ to $600^{\circ} \mathrm{C}$ with heating rate of $10 \% \mathrm{~min}$. The weight loss was recorded as a function of temperature.

\section{Py-GC/MS and GC/MS analysis}

For Py-GC/MS with thermally assisted hydrolysis and methylation method (THM) [9], a small amount of homogenized sample was loaded in a quartz tube closed with quartz wood, then $5 \mu l$ of tetramethyl ammonium hydroxide (TMAH) at $25 \% \mathrm{w} / \mathrm{w}$ in water were added. The quartz tube was inserted in the filament coil of the probe of a CDS Pyroprobe 1000 pyrolyser. Pyrolysis was performed at $600{ }^{\circ} \mathrm{C}$ for 10 seconds, with the interface maintained at $280{ }^{\circ} \mathrm{C}$, fluxed with helium and directly connected to the GC column. The GC was a 6890N Network GC System (Agilent Technologies, USA) with a methyl-phenyl-polysiloxane cross-linked 5\% phenyl methyl silicone (30 $\mathrm{m}, 0.25 \mathrm{~mm}$ internal diameter, $0.25 \mu \mathrm{m}$ film thickness) capillary column. The program temperature was: $50{ }^{\circ} \mathrm{C}$ (held for 2 minutes), then a temperature program to $300{ }^{\circ} \mathrm{C}$ (heating rate $10^{\circ} \mathrm{C} / \mathrm{min}$ to 
$130^{\circ} \mathrm{C}, 5^{\circ} \mathrm{C} / \mathrm{min}$ to $180^{\circ} \mathrm{C} / \mathrm{min}$, then $15^{\circ} \mathrm{C} / \mathrm{min}$ to $300^{\circ} \mathrm{C}$, held for 5 minutes). The carrier gas was helium $(1.0 \mathrm{~mL} / \mathrm{min})$ and the split ratio was $1 / 20$ of the total flow. The mass spectrometer coupled to the GC apparatus was a 5973 Network Mass Selective Detector (Agilent Technologies). Mass spectra were recorded under electron impact at $70 \mathrm{eV}$, scan range $40-600 \mathrm{~m} / \mathrm{z}$. The interface was kept at $280^{\circ} \mathrm{C}$, the ion source at $230{ }^{\circ} \mathrm{C}$ and the quadrupole mass analyzer at $150{ }^{\circ} \mathrm{C}$.

For what concerns GC/MS analyses, according to a previously described procedure suitable to the analysis of lipid and resinous materials in archaeological residues [10], samples (1-3 mg) were subjected to saponification with $10 \%$ hydroalcoholic KOH. Neutral organic components were extracted with n-hexane and, after acidification, the acidic organic components were extracted from the residual solution with diethyl ether. Aliquots of both the extracts were derivatised with N,OBis(trimethyl)-silyl-trifluoroacetamide (BSTFA) containing $1 \%$ trimethylchlorosilane using isooctane as a solvent. Of these, $2 \mu \mathrm{l}$ were analysed by GC/MS using hexadecane and tridecanoic acid as internal standards. The instrumentation (Agilent Technologies) consisted of a $6890 \mathrm{~N}$ gas chromatograph coupled with a 5973 single quadrupole mass spectrometer equipped with a PTV injector. The mass spectrometer was operated in the EI positive mode $(70 \mathrm{eV})$. The MS transfer line temperature was $280{ }^{\circ} \mathrm{C}$; the $\mathrm{MS}$ ion source temperature was $230{ }^{\circ} \mathrm{C}$; the $\mathrm{MS}$ quadrupole temperature was $150{ }^{\circ} \mathrm{C}$. Chromatographic separation was performed on a HP-5MS fused silica capillary column (J\&W Scientific, Agilent Technologies) coupled with a deactivated silica precolumn using a quartz press fit. The carrier gas was used in the constant flow mode (He, purity $99.995 \%$ ) at $1.2 \mathrm{ml} / \mathrm{min}$. The $\mathrm{GC}$ conditions were as follows: initial temperature $80^{\circ} \mathrm{C}, 2 \mathrm{~min}$ isothermal, $10^{\circ} \mathrm{C} / \mathrm{min}$ up to $200^{\circ} \mathrm{C}, 4 \mathrm{~min}$ isothermal, $6^{\circ} \mathrm{C} / \mathrm{min}$ up to $280^{\circ} \mathrm{C}, 40 \mathrm{~min}$ isothermal. Peak assignation was based on comparison with fatty acid standard solution, with library spectra (NIST 1.7), and with spectra reported in literature. Samples have been also analyzed for the presence of monosaccharides after hydrolysis according to a procedure suited to specifically investigate the presence of polysaccharidic gums [11].

\section{RESULTS AND DISCUSSION}

The compositional features of the nine examined black powders are summarized in Table 2 .

\section{SEM-EDX analysis}

Morphological and compositional characterization of powders was made by SEM-EDX on a reduced but representative portion of the powders, obtained by a statistical sampling, then lapped and polished. 
The morphological general images in backscattered electrons of the nine investigated black powders showed that all of them are composed of granules having shapes, sizes and compositions varying in wide ranges (Fig. 2a for 12724 powder). In general, granule shapes varied from rounded to angular and diameters ranged from 250 to $1500 \mu \mathrm{m}$.

For what concerns composition, the microprobe analysis showed that, excluding 12724 powder (type 1 vessel) which is only constituted by organic granules (Fig. 2b), all powders contain both organic granules with inorganic crystals dispersed inside them and completely inorganic granules. For sake of brevity, EDX spectra were not shown. The identification of organic residues was made on powders analyzed without deposition of graphite and was confirmed by the absence of chlorine, contained in the resin araldite used for the lapping process (see "Experimental" section).

For all powders contained in type 1 vessel (5402A, 12458B, 12724, 12747B, 12747C), the organic granules (Fig. 2b) included net-edged crystals of calcium sulphate bihydrate (gypsum), which in some samples (5402A, 12458B, 12724) is intimately associated to strontium sulphate (celestine). The net edges of gypsum crystals exclude that they were grown inside the organic matrix by percolation of water and suggest that they were intentionally added to the powder. This attribution is confirmed by the contemporary presence in some powders of gypsum and celestine, related to minerals coming from the "gessoso-solfifera" geologic formation, present in the Appenines and completely absent in the Pompeii zone.

Point analysis of the crystals dispersed inside the organic granules showed the presence of calcium carbonate (calcite) for powders 5402A, 12458B, 12724 (type 1 vessel); the presence of copper, lead and quartz for powders 12688 A (type 2 vessel) and 7147 (type 3 vessel); the presence of gypsum for 54785 (type 2 vessel) and the presence of copper oxide (cuprite) for 13011 (type 3 vessel).

The compositional features of the organic granules allow to identify powders contained in type 1 vessel as a homogeneous group, unlike powders contained in type 2 and 3 vessels (Table 2).

Completely inorganic granules were also observed in all samples, except 12724 powder, and appear as aggregates of several inorganic micro-crystals. In particular, in powder 5402A (type 1 vessel), the microprobe analysis showed that the inorganic granules contain copper oxide (cuprite); also granules of quartz, of malachite and of azurite were observed.

In powder 12458B (type 1 vessel), inorganic granules (Fig. 2c) containing calcium and magnesium carbonate (dolomite) and granules of calcium carbonate (calcite) and of malachite were observed. In powders 12747B, 12747C (type 1 vessel), 12688A and 54785 (type 2 vessel), 7147 and 13011 (type 3 vessel), point analysis showed the presence of metal silicates, phosphates, sulphates, mainly of lead, aluminium and calcium. Microprobe analysis showed also the presence of calcite in 54785 
and 13011, of anglesite in 12688A, of azurite in 12747B, 12747C and 13011, and of malachite in 7147 and 13011 powders.

In some samples the presence of granules probably related to contamination phenomena were also observed. In powder 12458B, silicate granules with bubble cavities were identified as pumice coming from the volcano eruption, while filaments of copper carbonate (Fig. 2d for 12458B powder), tin and tin/lead alloy were probably detached from the bronze vessels which contained powders.

\section{FTIR characterization}

Fourier-Transformed infrared (FTIR) characterization allowed the identification of distinctive vibrational features that have been correlated to the presence of specific compounds.

The vibrational investigation confirms the results obtained at the SEM-EDX and XRD analysis (Table 2).

Between the five examined samples contained in cases of type 1 (cylindrical vessels), some similarities can be highlighted. Four of five samples (12458B, 12724, 12747B, 12747C), contain gypsum $\left(\mathrm{CaSO}_{4} \cdot 2 \mathrm{H}_{2} \mathrm{O}\right)$, recognizable by peaks at 3545, 3404, 1686, 1621, 670 and $604 \mathrm{~cm}^{-1}$, and oxidized copper residues (wires, filaments, etc.). Three samples contain blue or green copper minerals: in particular, malachite $\left(\mathrm{Cu}_{2}\left(\mathrm{CO}_{3}\right)(\mathrm{OH})_{2}\right)$ was observed in samples 5402A and 12458B; azurite $\left(\mathrm{Cu}_{3}\left(\mathrm{CO}_{3}\right)_{2}(\mathrm{OH})_{2}\right)$ was observed in samples 5402A and 12747B. Two of five samples (12724 e 12747C) contain calcite $\left(\mathrm{CaCO}_{3}\right)$; the presence of calcite cannot be excluded in sample 5402A because of the contemporaneous presence of other constituents (malachite and azurite) that have strong peaks that overlap in the same vibrational regions.

Concerning samples conserved in containers of type 2 (unguentaries), the two powders analyzed are very different from each other. In particular, sample 54785 contains calcite and gypsum, similarly to samples $12747 \mathrm{C}$ and 12724 , while sample $12688 \mathrm{~A}$ is a mixture of organic and inorganic compounds.

Also the two samples found in containers of type 3 (aryballoi) are very different from each other. Sample 13011 contains both basic copper carbonates (malachite and azurite) and calcite.

The spectrum of sample 7147 (Fig. 3), very similar to that of sample 12688A, is complex because of the contemporary presence of organic and inorganic compounds. In both samples, the typical peaks of an organic compound, compatible with a vegetable oil, are present: $v_{\mathrm{CH} 2}$ at 2925 and 2854 $\mathrm{cm}^{-1}, v_{\mathrm{C}=\mathrm{O}}$ at 1729 and $1713 \mathrm{~cm}^{-1}, v_{\mathrm{COO}}$ at $1556 \mathrm{~cm}^{-1}, \delta_{\mathrm{CH} 2}$ of aliphatic chains at 1461 and $1453 \mathrm{~cm}^{-}$ ${ }^{1}, v_{\mathrm{C}-\mathrm{O}}$ at $1162 \mathrm{~cm}^{-1}$ and $\delta_{\mathrm{C}=\mathrm{C}-\mathrm{H}}$ at $724 \mathrm{~cm}^{-1}$. Other distinctive features present in these spectra, 
concerning the inorganic part of the sample, are the peaks of calcite at 1409 and $871 \mathrm{~cm}^{-1}$ and a peak of silicates at $1034 \mathrm{~cm}^{-1}$.

\section{Raman characterization}

The Raman spectra of all powders show two active modes at 1566 and $1337 \mathrm{~cm}^{-1}$, assigned to symmetry modes of disordered $\mathrm{sp}^{2}$ carbon (Fig. 4a, sample 12458B).

In samples 5402A, 12458B (Fig. 4b), 12724 (type 1 vessel), 12688A and 54785 (type 2 vessel), calcium carbonate (calcite) was also observed.

Gypsum has been identified in all powders (Fig. 4c, sample 12458B), except in 12688A (type 2 vessel), 7147 and 13011 (both in type 3 vessel).

Quartz in 5402A, diopside and anatase in $12458 \mathrm{~B}$ and anglesite in 12688A powders were also observed.

Finally, all powders, except 12688A and 54785 (both in type 2 vessel), contain copper carbonate (malachite and/or azurite), probably due to the corrosion of the walls of the bronze vessels which contained powders.

The results of Raman characterization are in agreement with those obtained by SEM-EDX, FTIR and XRD (see below) and show that the presence of gypsum seems to be characteristics of powders contained in type 1 vessel.

\section{XRD investigation}

Only seven of the nine samples studied in this paper have been analyzed by XRD because this non destructive technique requires a certain amount (at least $0.05 \mathrm{~g}$ ) of samples, and instead powders 5402A and 7147 were available only in small amounts.

For the analyzed samples, XRD analysis revealed that powders found in containers of type 1 form a homogeneous group, unlike those in type 2 and 3 containers. The XRD results confirm those obtained by SEM-EDX, FTIR and Raman.

All the examined samples present in type 1 containers (12458B, 12724, 12747B and 12747C) contain gypsum. Two of them (12724 and 12747C) contain also calcite, while 12458B and 12747B powders contain basic copper carbonates, in particular 12458B contains malachite and 12747B azurite. Powder $12458 \mathrm{~B}$ contains also silicates.

The two samples found in containers of type 2 (12688A and 54785) present a very different diffraction pattern from each other. Both contain calcite, but the sample 54785 present a well 
defined and simple pattern, in which only peaks of gypsum and calcium carbonate are visible, while the diffraction pattern of sample 12688A is more complex, with a large number of peaks, due to the contemporaneous presence of silicates.

Of the two samples found in containers of type 3 (7147 and 13011), only 13011 has been analyzed by XRD. This sample present a complex diffraction pattern in which peaks of calcite, aragonite, malachite and azurite are recognizable.

Some diffraction patterns (12458B, 12688A, 12747B) present a distorted and not linear baseline that indicates the presence of amorphous phases. This is compatible with the presence of organic compounds that are revealed by other techniques.

\section{EPR characterization}

The characterization by EPR spectroscopy was aimed at identifying and quantifying the paramagnetic species present in powders.

For all samples contained in vessels 1, 2 and 3, several broad lines were observed (from $\sim 800 \mathrm{G}$ to $\sim 1500 \mathrm{G}$ wide), which suggest the presence of several metal species not precisely identifiable, but in agreement with the observation of several metal species by SEM-EDX, FTIR, Raman and XRD analysis. Furthermore, for all samples except 13011 powder, sharp isotropic signals centred at $\mathrm{g}=$ $2.002 \pm 0.003$ were observed. The peak-to-peak line width $\left(\Delta \mathrm{H}_{\mathrm{pp}}\right)$ of these signals ranged from 3.82 $\mathrm{G}$ for 12458B (Fig. 5a) and 7147 to $6.85 \mathrm{G}$ for $12747 \mathrm{C}$ (Fig. 5b), with intermediate values of 3.90 $\mathrm{G}$ for $12724,4.13 \mathrm{G}$ for $5402 \mathrm{~A}$ and $54785,4.48 \mathrm{G}$ for $12688 \mathrm{~A}, 4.76 \mathrm{G}$ for $12747 \mathrm{~B}$. The absolute concentrations of these radicals are very high, $\sim 10^{17} \mathrm{spin} / \mathrm{g} \pm 10 \%$.

The g-value and the line widths suggest the attribution of the sharp signals to carbon radicals formed after heat treatment of powders, which have an almost infinite stability at ambient conditions due to their insertion in aromatic structures [12]. The presence of carbon radicals is in agreement with the organic portion observed at SEM-EDX and Raman investigation. The long-term stability of radical carbons and the ease of observation of their EPR signals have allowed to use them as indicators of the previous heating of archaeological materials. In particular, the g-values of carbon radicals were found to depend on the heating temperature but not on the heating time, while their $\Delta \mathrm{H}_{\mathrm{pp}}$ values depend on both the temperature and heating time, unfortunately in a manner difficult to rationalize [12]. Thus, the observation on all Pompeii powders, except 13011, of carbon radical signals having the same g-value and different values of $\Delta \mathrm{H}_{\mathrm{pp}}$ suggests that the examined powders experienced the same heating temperature for different heating times. 
Powder 13011 in type 3 vessel showed an isotropic signal at $\mathrm{g}=1.999$ (not shown), having a line width of $\sim 46.00 \mathrm{G}$, probably due to a metal species, difficult to assign since it is overlapped to several other broad signals. The EPR spectrum suggests that 13011 powder is significantly different from the other powders, since in its organic portion stable carbon radicals were not present.

\section{TGA analysis}

Thermogravimetric analyses in dry air were performed with the aim of obtaining the inorganic fraction percentage, represented by the residue obtained after the analysis. Results for all sample are reported in Table 2. With the exclusion of sample 12688 A, all samples show an high inorganic residue percentage, between 40 to $76 \%$, in agreement with organic analysis (py-GC/MS and GC/MS, see below). In particular, it is possible to observe that samples with minor amount of lipids are those with higher inorganic fraction, as well exemplified by sample 54785 (see Table 3 for organic composition).

\section{Py-GC/MS and GC/MS analysis}

Analyses by Py-GC/MS with thermally assisted hydrolysis and methylation and by GC/MS after saponification permitted to investigate the composition of the organic fractions of the samples at a molecular level. In particular, Py-GC/MS achieves information on a wide range of components (lipids, polysaccharides, terpenic resins), including high molecular weight or reticulated fractions without any sample pre-treatment. Py-GC/MS results have been confirmed by GC/MS analysis, specifically aimed to assess the fatty acid profile and the degree of oxidation and degradation of lipid and terpenic components, and to assess the presence of sterols and other neutral compounds in the unsaponifiable fraction.

All the samples, except 13011, contain a consistent amount of lipid material. Some of the samples contained polycyclic aromatic hydrocarbons (PAH) and traces of diterpenic structures. A few of the samples showed traces of polysaccharide material at blank level, which were considered nonsignificant and due to environmental contamination in the archaeological site.

On the basis of the organic composition and of the abundance and profile of fatty acids, it has been possible to clearly individuate the samples deriving from bronze cylindrical containers (type 1 vessel: $5402 \mathrm{~A}, 12458 \mathrm{~B}, 12724,12747 \mathrm{~B}, 12747 \mathrm{C})$ as a homogeneous group, different from the samples contained in type 2 and 3 vessels.

Fig. 6a and 7 show the Py-GC/MS and GC/MS profiles respectively of samples 12747 (by PyGC/MS) and 12724 (by GC/MS), representative of the powders contained in type 1 vessel. They are 
characterized by the presence of a large amounts of several polycyclic aromatic hydrocarbons (PAH), which are indicative of a carbon black pigment deriving from the combustion of wood. Vanillic acid, highlighted in some powders, is also an indication of the wood origin of the material. On the basis of the presence of retene and other tricyclic PAH that can derive from an abietane diterpenic structure, it can be hypothesized that the wood used to prepare the pigment is a conifer wood of the family of Pinaceae.

Powders in type 1 vessel are also characterized by the presence of fatty acids, with prevalence of hexadecanoic (palmitic), octadecanoic (stearic) and 9-octadecenoic (oleic) acids. The composition of the samples of this group appears identical, apart small differences in the relative amounts of PAHs and fatty acids.

The presence of the unsaturated chain of oleic acid, and the relatively limited abundance of dicarboxylic acids (e.g. nonandioic acid, azelaic) and of other oxidation products indicates that this lipid material had not been subjected to deep alteration or oxidation. An animal origin can be hypothesized, on the basis of the non-negligible amounts of odd carbon number chain fatty acids (pentadecanoic and heptadecanoic) and of the presence of cholesterol in the neutral fraction. Nevertheless, due to the unspecifity of the fatty acid composition it is not possible to ascertain more precisely the origin of the lipid material, and neither to exclude the possibility of a mixture of animal fat and plant oil.

The powders contained in type 2 and 3 vessels show a less homogeneous composition.

Samples 54785 and 12688A (Fig. 6b), collected from type 2 vessel, show indication of lipids, but with a different molecular profile, and they do not contain PAHs. In particular, sample 54785 has a fatty acid profile similar to that of the samples contained in the bronze cylindrical containers discussed before, with prevalence of $\mathrm{C} 16$ and C18 chains, low degree of oxidation, and presence of small but not negligible amounts of pentadecanoic acid, heptadecanoic acid and cholesterol, suggesting an animal origin or a mixture of vegetal and animal lipids.

Sample 12688A has a more peculiar lipid composition. It contains some odd atom carbon fatty acids $(\mathrm{C} 15, \mathrm{C} 17, \mathrm{C} 19)$ that indicate the presence of an animal fat, but it also shows longer chain fatty acids (up to C24) and a higher degree of oxidation, with respect to the previously discussed samples. Unsaturated chains are absent, while consistent amounts of dicarboxylic acids with carbon number between 6 and 11 are observed. Dicarboxylic acids are not present in native lipids, but are formed as a product of oxidation reactions. Short chain n-alkanes/1-alkenes and short chain fatty acids are also present, which can suggest that a plant wax of unknown origin has been included in the formulation of the material. The absence of long chain linear hydrocarbons, and of long chain alcohols after saponification, excludes the presence of beeswax. 
Samples 13011 and 7147, from type 3 vessels, do not contain PAHs. Sample 13011 can be distinguished from all the others because it does not contain a significant level of lipid materials, and, apart from some aromatic compounds (see Table 3) and traces of fatty acids (palmitic and stearic) which can derive from an environmental contamination, it is possible to assume that this materials has a negligible organic fraction. On the other hand, sample 7147 (see Fig. 6c) contains a large amount of organic compounds, with a molecular profile different from the other samples. In particular it is possible to observe a consistent amount of mono- and di-unsaturated fatty acids (oleic acid and linoleic acid), together with their oxidation products: dicarboxilic acids (with nonandioic acid as the more abundant) and hydroxy-acids. The abundance of mono- and diunsaturated fatty acids in this sample suggests the presence of a drying or semi-drying plant oil, yet not completely degraded or oxidized. In the neutral fraction, a large amount of sitosterol is detected, accompanied by only traces of cholesterol. This indicates a prevalence of plant origin for the organic fraction of sample 7147.

\section{CONCLUSIONS}

The present paper shows the results of a multi-analytical approach for the characterization of nine black powders found in 3 different types of bronze vessels (cylindrical theca atramentaria, unguentaries and aryballoi) found in Pompeii houses.

On the basis of both organic and inorganic compositions, it has been possible to identify all powders contained in cylindrical theca atramentaria as writing inks, in agreement with the archaeologists hypothesis, while powders contained in unguentaries and aryballoi may have had several different uses, including those as writing inks or as cosmetics.

The assignment as writing inks of powders contained in cylindrical theca atramentaria is mainly based on the presence of large amounts of several polycyclic aromatic hydrocarbons, indicative of carbon black pigments deriving from the combustion of wood in want of air, and on the presence of gypsum, probably used to accelerate the page drying. In some powders of this group also calcite was observed, which could derive from the known procedure for the preparation of carbon-based inks, which involved the dissolution of soot and Arabic gum with common hard waters. Unfortunately, Arabic gum is rarely detected in ancient samples due to its faint durability in the environment. The detected glycerolipids of animal origin can be related to the presence of animal glue prepared by lengthy boiling animal remains, which was used in the preparation of papyri. 
As a whole, the composition profile of the powders found in cylindrical cases shows that at 79 A.D. in Pompeii archaeological site carbon-based inks were still used for writing, and iron-gall inks had not been introduced yet.

\section{ACKNOWLEDGEMENTS}

The authors thank the Italian MIUR for financial support of the Project PRIN2007 "Colors and balms in antiquity: from the chemical study to the knowledge of technologies in cosmetics, painting and medicine" (Prot. 2007AKK9LX) and the "Soprintendenza Speciale per i Beni Archeologici di Napoli e Pompei” for permits granted.

\section{FIGURE CAPTIONS}

Fig. 1 Bronze vessels: (a) cylindrical case (type 1), (b) unguentary (type 2) and (c) aryballos (type 3). The ruler corresponds to $5 \mathrm{~cm}$

Fig. 2 SEM-EDX images of samples: (a) and (b) 12724, (c) and (d) 12458B

Fig. 3 FTIR spectrum of sample 7147

Fig. 4 Raman spectra recorded on 12458 B: (a) carbon, (b) calcite, (c) calcium sulfate dihydrate Fig. 5 X-band EPR spectra recorded at room temperature on (a) 12458B and (b) 12747C powders Fig. 6 Pyrograms obtained by THM Py-GC/MS of the samples: (a) 12747, (b) 12688A and (c) 7147. See Table 3 for peak assignments

Fig. 7 Total ion current chromatogram of the acidic (a) and neutral (b) fraction of sample 12747. (IS1 = hexadecane, IS2 = tridecanoic acid). The acidic species are present as TMS-derivatives. Cx:y: linear monocarboxylic acid with $\mathrm{x}$ carbon atoms and y-insaturations; diCx: dicarboxylic acid with $\mathrm{x}$-carbon atoms; $\bullet$ : polycyclic aromatic hydrocarbons (PAHs)

\section{REFERENCE LIST}

1. Eerkens JW, Barnard H (2007) Theory and practice of archaeological residues analysis. Barnard $\mathrm{H}$ and Eerkens JW eds. BAR International Series S1650. Archaeopress. Oxford

2. Ribechini E, Colombini MP, Giachi G, Modugno F, Pallecchi P (2009) A multi-analytical approach for the characterization of commodities in a ceramic jar from Antinoe (Egypt). Archaeometry 51 (3): 480-494 
3. Lucas A, Harris JR (1962) Ancient Egyptian Materials and Industries. Arnold, London.; Lucas A (1922) The Inks of Ancient and Modern Egypt. The Analyst 9-14

4. Dioskurides PA (2005) De Materia Medica. L.Y. Beck. transl. Hildesheim

5. Pliny the Elder (1983), Naturalis Historia. Latin text with Italian translation. Einaudi, Turin

6. Capella M (1978) De nuptiis philologiae et mercurii. Adolfus Dick ed., Stuttgart

7. Nir-El Y, Broshi M (1996) The black ink of the Qumran Scrolls, Dead sea Discoveries 3(2): 157 167

8. Mc Crone Associates (2000) Ink Analysis: the Gospel of Judas. Www.mccroneassociates.com/case-studies/gospel-of-judas

9. Challinor JM (2001) Review: the development and applications of thermally assisted hydrolysis and methylation reactions. J Anal Appl Pyrolysis 61:3-34

10. Colombini MP, Giachi G, Modugno F, Pallecchi P, Ribechini E (2003) The characterization of paints and waterproofing materials from the shipwrecks found at the archaeological site of the Etruscan and Roman harbour of Pisa (Italy). Archaeometry 45 (4):659-674

11. Lluveras A, Bonaduce I, Andreotti A, Colombini MP (2009) GC/MS Analytical Procedure for the Characterization of Glycerolipids, Natural Waxes, Terpenoid Resins, Proteinaceous and Polysaccharide Materials in the Same Paint Microsample Avoiding Interferences from Inorganic Media. Anal Chem 82 (1):376-386

12. Aydas C, Engin B, Donmez EO, Belli O (2010) The use of ESR technique for assessment of heating temperatures of archaeological lentil samples. Spectrochim. Acta Part A 75:466-473

Table 1 - Area of provenance and vessel description for the examined powders found in Pompei houses.

\begin{tabular}{|l|l|l|l|}
\hline Powder & $\begin{array}{l}\text { Area of provenance } \\
\text { (Regio, Insula, N.) }\end{array}$ & Vessel description & Vessel type \\
\hline $\mathbf{5 4 0 2} \mathbf{A}$ & I, $10,7$. & Cylindrical theca atramentaria & 1 \\
\hline $\mathbf{1 2 4 5 8 B}$ & I, $18,5$. & Cylindrical theca atramentaria with cap & 1 \\
\hline $\mathbf{1 2 7 2 4}$ & I, $11,17$. & Cylindrical theca atramentaria & 1 \\
\hline $\mathbf{1 2 7 4 7} \mathbf{B}$ & I, $11,7$. & Cylindrical theca atramentaria with cap & 1 \\
\hline $\mathbf{1 2 7 4 7} \mathbf{C}$ & I, $11,7$. & $\begin{array}{l}\text { Cylindrical theca atramentaria with } \\
\text { disassembled cap }\end{array}$ & 1 \\
\hline $\mathbf{1 2 6 8 8} \mathbf{A}$ & I, $11,15$. & Unguentary & 2 \\
\hline $\mathbf{5 4 7 8 5}$ & V, 3, not known & Unguentary & 2 \\
\hline $\mathbf{7 1 4 7}$ & I, $8,12$. & Aryballos & 3 \\
\hline $\mathbf{1 3 0 1 1}$ & Not known & Aryballos & 3 \\
\hline
\end{tabular}


Table 2 - Compositional features of the nine black powders found in type 1, 2 and 3 bronze vessels.

\begin{tabular}{|c|c|c|c|c|c|c|c|c|}
\hline Powder & $\begin{array}{l}\text { Type } \\
\text { of } \\
\text { vessel }\end{array}$ & SEM-EDX & FTIR & Raman & XRD & EPR & TGA & $\begin{array}{l}\text { GC/MS, } \\
\text { Py-GC/MS }\end{array}$ \\
\hline $5402 A$ & 1 & $\begin{array}{l}\text { Organic } \\
\text { granules with } \\
\text { calcite, } \\
\text { gypsum, } \\
\text { celestine. } \\
\text { Granules of } \\
\text { cuprite. } \\
\text { Quartz; } \\
\text { malachite } \\
\text { azurite; tin. }\end{array}$ & $\begin{array}{l}\text { Malachite, } \\
\text { azurite; } \\
\text { possible } \\
\text { presence } \\
\text { of calcite. }\end{array}$ & $\begin{array}{l}\text { Carbon, } \\
\text { calcite, } \\
\text { gypsum, } \\
\text { quartz, } \\
\text { azurite. }\end{array}$ & $\begin{array}{l}\text { Not } \\
\text { examined }\end{array}$ & $\begin{array}{l}\text { Carbon } \\
\text { radicals } \\
\text { and } \\
\text { metal } \\
\text { species. }\end{array}$ & $\begin{array}{l}\text { Not } \\
\text { examined. }\end{array}$ & $\begin{array}{l}\text { Glycerolipids } \\
\text { of animal or } \\
\text { animal + plant } \\
\text { origin; PAHs }\end{array}$ \\
\hline 12458B & 1 & $\begin{array}{l}\text { Organic } \\
\text { granules with } \\
\text { calcite, } \\
\text { gypsum, } \\
\text { celestine. } \\
\text { Granules of } \\
\text { dolomite and } \\
\text { calcite. } \\
\text { Malachite; } \\
\text { pumice; } \\
\text { tin/lead } \\
\text { alloy. }\end{array}$ & $\begin{array}{l}\text { Gypsum, } \\
\text { malachite, } \\
\text { silicates }\end{array}$ & $\begin{array}{l}\text { Carbon, } \\
\text { barite, } \\
\text { calcite, } \\
\text { gypsum, } \\
\text { malachite, } \\
\text { diopside, } \\
\text { anatase. }\end{array}$ & $\begin{array}{l}\text { Gypsum, } \\
\text { malachite, } \\
\text { silicates }\end{array}$ & $\begin{array}{l}\text { Carbon } \\
\text { radicals } \\
\text { and } \\
\text { metal } \\
\text { species. }\end{array}$ & $\begin{array}{l}40 \% \\
\text { inorganic } \\
\text { residue }\end{array}$ & $\begin{array}{l}\text { Glycerolipids } \\
\text { of animal or } \\
\text { animal + plant } \\
\text { origin; PAHs }\end{array}$ \\
\hline 12724 & 1 & $\begin{array}{l}\text { Organic } \\
\text { granules with } \\
\text { calcite, } \\
\text { gypsum, } \\
\text { celestine. }\end{array}$ & $\begin{array}{l}\text { Calcite, } \\
\text { gypsum. }\end{array}$ & $\begin{array}{l}\text { Carbon, } \\
\text { calcite, } \\
\text { gypsum, } \\
\text { malachite. }\end{array}$ & $\begin{array}{l}\text { Calcite, } \\
\text { gypsum. }\end{array}$ & $\begin{array}{l}\text { Carbon } \\
\text { radicals } \\
\text { and } \\
\text { metal } \\
\text { species. }\end{array}$ & $\begin{array}{l}68 \% \\
\text { inorganic } \\
\text { residue }\end{array}$ & $\begin{array}{l}\text { Glycerolipids } \\
\text { of animal or } \\
\text { animal + plant } \\
\text { origin; PAHs }\end{array}$ \\
\hline 12747B & 1 & $\begin{array}{l}\text { Organic } \\
\text { granules with } \\
\text { gypsum. } \\
\text { Granules } \\
\text { containing } \\
\text { metal } \\
\text { silicates, } \\
\text { phosphates } \\
\text { and } \\
\text { sulphates. } \\
\text { Azurite; tin. }\end{array}$ & $\begin{array}{l}\text { Gypsum, } \\
\text { azurite }\end{array}$ & $\begin{array}{l}\text { Carbon, } \\
\text { gypsum, } \\
\text { azurite. }\end{array}$ & $\begin{array}{l}\text { Gypsum, } \\
\text { azurite }\end{array}$ & $\begin{array}{l}\text { Carbon } \\
\text { radicals } \\
\text { and } \\
\text { metal } \\
\text { species. }\end{array}$ & $\begin{array}{l}59 \% \\
\text { inorganic } \\
\text { residue }\end{array}$ & $\begin{array}{l}\text { Glycerolipids } \\
\text { of animal or } \\
\text { animal + plant } \\
\text { origin; PAHs }\end{array}$ \\
\hline $12747 \mathrm{C}$ & 1 & $\begin{array}{l}\text { Organic } \\
\text { granules with } \\
\text { gypsum. } \\
\text { Granules } \\
\text { containing } \\
\text { metal } \\
\text { silicates, } \\
\text { phosphates } \\
\text { and } \\
\text { sulphates. } \\
\text { Azurite; tin. }\end{array}$ & $\begin{array}{l}\text { Calcite, } \\
\text { gypsum. }\end{array}$ & $\begin{array}{l}\text { Carbon, } \\
\text { gypsum, } \\
\text { azurite. }\end{array}$ & $\begin{array}{l}\text { Calcite, } \\
\text { gypsum. }\end{array}$ & $\begin{array}{l}\text { Carbon } \\
\text { radicals } \\
\text { and } \\
\text { metal } \\
\text { species. }\end{array}$ & $\begin{array}{l}68 \% \\
\text { inorganic } \\
\text { residue }\end{array}$ & $\begin{array}{l}\text { Glycerolipids } \\
\text { of animal or } \\
\text { animal + plant } \\
\text { origin; PAHs }\end{array}$ \\
\hline 12688A & 2 & $\begin{array}{l}\text { Organic } \\
\text { granules } \\
\text { containing } \\
\text { copper, lead } \\
\text { and quartz. } \\
\text { Granules }\end{array}$ & $\begin{array}{l}\text { Organic } \\
\text { compound } \\
\text { s, calcite, } \\
\text { silicates. }\end{array}$ & $\begin{array}{l}\text { Carbon, } \\
\text { calcite, } \\
\text { anglesite. }\end{array}$ & $\begin{array}{l}\text { Calcite, } \\
\text { silicates. }\end{array}$ & $\begin{array}{l}\text { Carbon } \\
\text { radicals } \\
\text { and } \\
\text { metal } \\
\text { species. }\end{array}$ & $\begin{array}{l}24 \% \\
\text { inorganic } \\
\text { residue. }\end{array}$ & $\begin{array}{l}\text { Fatty acids } \\
\text { and } \\
\text { dicarboxylic } \\
\text { acids: lipids of } \\
\text { animal or } \\
\text { animal + plant }\end{array}$ \\
\hline
\end{tabular}




\begin{tabular}{|c|c|c|c|c|c|c|c|c|}
\hline & & $\begin{array}{l}\text { containing } \\
\text { anglesite, } \\
\text { metal } \\
\text { silicates, } \\
\text { phosphates } \\
\text { and } \\
\text { sulphates. } \\
\text { Tin. }\end{array}$ & & & & & & origin. \\
\hline 54785 & 2 & $\begin{array}{l}\text { Organic } \\
\text { granules } \\
\text { containing } \\
\text { gypsum. } \\
\text { Granules } \\
\text { containing } \\
\text { calcite, } \\
\text { metal } \\
\text { silicates, } \\
\text { phosphates } \\
\text { and } \\
\text { sulphates. } \\
\text { Tin. } \\
\end{array}$ & $\begin{array}{l}\text { Calcite, } \\
\text { gypsum. }\end{array}$ & $\begin{array}{l}\text { Carbon, } \\
\text { calcite, } \\
\text { gypsum. }\end{array}$ & $\begin{array}{l}\text { Calcite, } \\
\text { gypsum. }\end{array}$ & $\begin{array}{l}\text { Carbon } \\
\text { radicals } \\
\text { and } \\
\text { metal } \\
\text { species. }\end{array}$ & $\begin{array}{l}76 \% \\
\text { inorganic } \\
\text { residue. }\end{array}$ & $\begin{array}{l}\text { Fatty acids } \\
\text { and } \\
\text { dicarboxylic } \\
\text { acids: lipids of } \\
\text { animal or } \\
\text { animal + plant } \\
\text { origin. }\end{array}$ \\
\hline 7147 & 3 & $\begin{array}{l}\text { Organic } \\
\text { granules } \\
\text { containing } \\
\text { copper, lead } \\
\text { and quartz. } \\
\text { Granules } \\
\text { containing } \\
\text { metal } \\
\text { silicates, } \\
\text { phosphates } \\
\text { and } \\
\text { sulphates. } \\
\text { Malachite; } \\
\text { tin. }\end{array}$ & $\begin{array}{l}\text { Organic } \\
\text { compound } \\
\text { s, calcite, } \\
\text { silicates. }\end{array}$ & $\begin{array}{l}\text { Carbon, } \\
\text { malachite. }\end{array}$ & $\begin{array}{l}\text { Not } \\
\text { examined. }\end{array}$ & $\begin{array}{l}\text { Carbon } \\
\text { radicals } \\
\text { and } \\
\text { metal } \\
\text { species. }\end{array}$ & $\begin{array}{l}\text { Not } \\
\text { examined. }\end{array}$ & $\begin{array}{l}\text { Unsaturated } \\
\text { fatty acids } \\
\text { and } \\
\text { dicarboxylic } \\
\text { acids: } \\
\text { glycerolipids } \\
\text { of plant origin } \\
\text { (drying or } \\
\text { semidrying } \\
\text { oil). }\end{array}$ \\
\hline 13011 & 3 & $\begin{array}{l}\text { Organic } \\
\text { granules } \\
\text { containing } \\
\text { cuprite. } \\
\text { Granules } \\
\text { containing } \\
\text { calcite, metal } \\
\text { silicates, } \\
\text { phosphates } \\
\text { and } \\
\text { sulphates. } \\
\text { Malachite; } \\
\text { azurite; tin; } \\
\text { tin/lead } \\
\text { alloy. }\end{array}$ & $\begin{array}{l}\text { Malachite, } \\
\text { azurite, } \\
\text { calcite. }\end{array}$ & $\begin{array}{l}\text { Carbon, } \\
\text { malachite, } \\
\text { azurite. }\end{array}$ & $\begin{array}{l}\text { Malachite, } \\
\text { azurite, } \\
\text { calcite, } \\
\text { aragonite. }\end{array}$ & $\begin{array}{l}\text { Metal } \\
\text { species. }\end{array}$ & $\begin{array}{l}52 \% \\
\text { inorganic } \\
\text { residue. }\end{array}$ & $\begin{array}{l}\text { Organic } \\
\text { content } \\
\text { negligible. }\end{array}$ \\
\hline
\end{tabular}

Table 3 - Chromatographic peak assignments relative to the pyrograms in Fig. 6, and presence of the identified compounds in the pyrograms of the investigated samples.

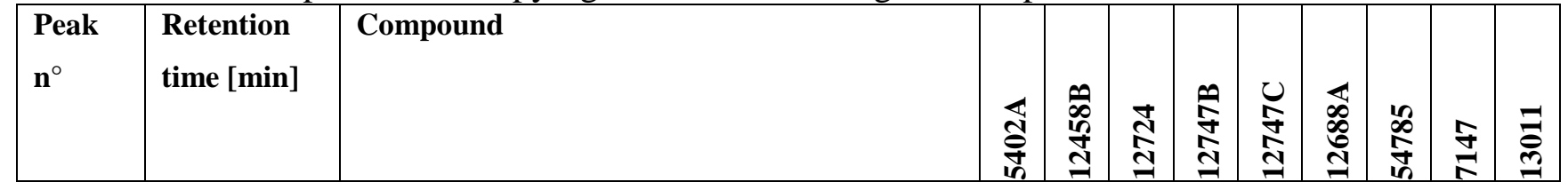




\begin{tabular}{|c|c|c|c|c|c|c|c|c|c|c|c|}
\hline 1 & 2,46 & 1-H-pyrrole, 1-methyl & & & & & & & $\mathrm{x}$ & & \\
\hline 2 & 2,62 & Benzene & & & & & & & & & $\mathrm{x}$ \\
\hline 3 & 2,69 & Acetic acid, methoxy-,methyl ester & & & & $\mathrm{x}$ & $\mathrm{x}$ & & & & \\
\hline 4 & 3,38 & Toluene & & & & & & & & & $\mathrm{X}$ \\
\hline 5 & 5,03 & Hexanoic acid, methyl ester & & & & & & $\mathrm{X}$ & & $\mathrm{x}$ & \\
\hline 6 & 5,20 & Methoxybenzene & & & & & & & & & $\mathrm{x}$ \\
\hline 7 & 6,65 & Heptanoic acid, methyl ester & & & & & & $\mathrm{X}$ & & $\mathrm{x}$ & \\
\hline 8 & 7,71 & 1-undecene & & & & & & $\mathrm{X}$ & & & \\
\hline 9 & 7,84 & undecane & & & & & & $\mathrm{X}$ & & & \\
\hline 10 & 7,90 & Benzoic acid, methyl ester & & & & & & & & & $\mathrm{X}$ \\
\hline 11 & 7,91 & Nonanale & & & & & & & & $\mathrm{x}$ & \\
\hline 12 & 8,23 & Octanoic acid, methyl ester & & & & & & $\mathrm{X}$ & & $\mathrm{x}$ & \\
\hline 13 & 8,24 & Methyl 1-methylpyrrole-2-carboxylate & & & & & & & $\mathrm{x}$ & & \\
\hline 14 & 9,20 & Napthalene & $\mathrm{x}$ & $\mathrm{x}$ & & $\mathrm{x}$ & $\mathrm{x}$ & & & & $\mathrm{X}$ \\
\hline 15 & 9,24 & 1-dodecene & & & & & & $\mathrm{X}$ & & & \\
\hline 16 & 9,36 & Dodecane & & & & & & $\mathrm{X}$ & & & \\
\hline 17 & 9,73 & Nonanoic acid, methyl ester & $\mathrm{x}$ & & & & & $\mathrm{x}$ & & $\mathrm{x}$ & \\
\hline 18 & 10,70 & 1-tridecene & & & & & & $\mathrm{X}$ & & & \\
\hline 19 & 10,82 & Tridecane & & & & $\mathrm{x}$ & $\mathrm{x}$ & $\mathrm{x}$ & & & $\mathrm{x}$ \\
\hline 20 & 11,41 & Heptandioic acid, dimethyl ester & & & & & & & & $\mathrm{x}$ & \\
\hline 21 & 11,55 & L-proline, 1-methyl-5-oxo-, methyl ester & & & & & & & $\mathrm{x}$ & & \\
\hline 22 & 12,21 & Decanoic acid, methyl ester & $\mathrm{x}$ & & & & & $\mathrm{X}$ & & & \\
\hline 23 & 12,30 & 1-tetradecene & & & & & & $\mathrm{x}$ & & & \\
\hline 24 & 12,44 & Tetradecane & & & & $\mathrm{x}$ & $\mathrm{x}$ & & & & $\mathrm{X}$ \\
\hline 25 & 12,76 & Octandioic acid, dimethyl ester & & & & & & & & $\mathrm{x}$ & \\
\hline 26 & 12,87 & Undecanoic acid, methyl ester & & & & & & $\mathrm{X}$ & & & \\
\hline 27 & 13,41 & Acenaphtylene & & $\mathrm{x}$ & & $\mathrm{x}$ & $\mathrm{x}$ & & & & \\
\hline 28 & 14,08 & 1-pentadecene & & & & & & $\mathrm{X}$ & & & \\
\hline 29 & 14,22 & Pentadecane & & & & & & $\mathrm{X}$ & & & \\
\hline 30 & 14,69 & Dodecanoic acid, methyl ester & $\mathrm{x}$ & & $\mathrm{x}$ & & & $\mathrm{x}$ & & & \\
\hline 31 & 15,17 & Nonandioic acid, dimethyl ester & & & & & & $\mathrm{X}$ & & $\mathrm{x}$ & \\
\hline 32 & 15,97 & 1-hexadecene & & & & & & $\mathrm{X}$ & & & \\
\hline 33 & 16,11 & Hexadecane & & & & & & $\mathrm{X}$ & & & \\
\hline 34 & 16,62 & Tridecanoic acid, methyl ester & & & & & & $\mathrm{X}$ & & & \\
\hline 35 & 17,93 & 1-heptadecene & & & & & & $\mathrm{x}$ & & & \\
\hline 36 & 18,07 & Heptadecane & & & & & & $\mathrm{X}$ & & & \\
\hline 37 & 18,60 & Tetradecanoic acid, methyl ester & $\mathrm{x}$ & & $\mathrm{x}$ & & $\mathrm{x}$ & $\mathrm{X}$ & & & $\mathrm{X}$ \\
\hline 38 & 19,64 & Anthracene & $\mathrm{x}$ & $\mathrm{x}$ & $\mathrm{x}$ & $\mathrm{x}$ & $\mathrm{x}$ & & & & \\
\hline 39 & 19,84 & Phenanthrene & $\mathrm{x}$ & $\mathrm{X}$ & $\mathrm{x}$ & $\mathrm{x}$ & $\mathrm{x}$ & & & & \\
\hline
\end{tabular}




\begin{tabular}{|c|c|c|c|c|c|c|c|c|c|c|c|}
\hline 40 & 20,51 & Pentadecanoic acid, methyl ester & & & & & & $\mathrm{x}$ & & & \\
\hline 41 & 21,59 & 1-methyl phenanthrene & $\mathrm{x}$ & & & $\mathrm{x}$ & $\mathrm{x}$ & & & & \\
\hline 42 & 21,61 & 9-hexadecenoi acid, methyl ester & $\mathrm{x}$ & & & & & & $\mathrm{x}$ & & $\mathrm{X}$ \\
\hline 43 & 21,90 & Hexadecanoic acid, methyl ester & $\mathrm{x}$ & $\mathrm{x}$ & $\mathrm{x}$ & $\mathrm{X}$ & $\mathrm{X}$ & $\mathrm{X}$ & $\mathrm{x}$ & $\mathrm{x}$ & $\mathrm{X}$ \\
\hline 44 & 22,44 & 2-phenyl naphtalene & $\mathrm{x}$ & & & $\mathrm{X}$ & & & & & \\
\hline 45 & 22,95 & Heptadecanoic acid, methyl ester & & & $\mathrm{x}$ & & & $\mathrm{X}$ & $\mathrm{x}$ & & \\
\hline 46 & 23,30 & Fluoranthene & $\mathrm{x}$ & $\mathrm{x}$ & $\mathrm{x}$ & $\mathrm{X}$ & $\mathrm{x}$ & & & & \\
\hline 47 & 23,61 & 9-octadecenoic acid, methyl ester & $\mathrm{x}$ & & & $\mathrm{X}$ & & $\mathrm{x}$ & $\mathrm{x}$ & $\mathrm{x}$ & $\mathrm{x}$ \\
\hline 48 & 23,77 & Pyrene & $\mathrm{x}$ & $\mathrm{x}$ & $\mathrm{x}$ & $\mathrm{X}$ & $\mathrm{x}$ & & & & \\
\hline 49 & 23,82 & Octadecanoic acid, methyl ester & $\mathrm{x}$ & $\mathrm{x}$ & $\mathrm{x}$ & $\mathrm{X}$ & $\mathrm{x}$ & $\mathrm{x}$ & $\mathrm{x}$ & $\mathrm{x}$ & $\mathrm{X}$ \\
\hline 50 & 24,04 & 9,12-octadecadienoic acid, methyl ester & & & & & & & & $\mathrm{x}$ & \\
\hline 51 & 24,35 & 1-methyl pyrene & & & & $\mathrm{X}$ & $\mathrm{x}$ & & & & \\
\hline 52 & 24,44 & 9,11-octadecadienoic acid, methyl ester & & & & & & & & $\mathrm{x}$ & \\
\hline 53 & 24,57 & Nonadecanoic acid, methyl ester & & & & & & $\mathrm{X}$ & & & \\
\hline 54 & 24,58 & Phenanthrene, 1-methyl-7-(1-methylethyl) & $\mathrm{x}$ & $\mathrm{x}$ & $\mathrm{X}$ & $\mathrm{X}$ & $\mathrm{x}$ & & & & \\
\hline 55 & 24,90 & 4-methyl pyrene & & & & $\mathrm{X}$ & $\mathrm{x}$ & & & & \\
\hline 56 & 25,10 & 1,4-dimethyl-2-phenyl-naphtalene & & & & $\mathrm{X}$ & $\mathrm{x}$ & & & & \\
\hline 57 & 25,24 & Eicosanoic acid, methyl ester & & & $\mathrm{X}$ & & & $\mathrm{x}$ & & & \\
\hline 58 & 25,24 & Methyl 9,10-epoxyoctadecanoate & & & & & & & & $\mathrm{x}$ & \\
\hline 59 & 25,45 & Octadecanoic acid, 9-oxo-, methyl ester & & & & & & & & $\mathrm{x}$ & \\
\hline 60 & 25,79 & Benzo[ghi]fluoranthene & & $\mathrm{X}$ & & $\mathrm{X}$ & $\mathrm{x}$ & & & & \\
\hline 61 & 25,87 & Methyl 7-acetoxytetradecanoate & & & & & & & & $\mathrm{x}$ & \\
\hline 62 & 25,88 & Cyclopenta[cd]pyrene & $\mathrm{x}$ & & $\mathrm{x}$ & & & & & & \\
\hline 63 & 26,16 & Benzanthracene & $\mathrm{x}$ & $\mathrm{x}$ & $\mathrm{x}$ & $\mathrm{x}$ & $\mathrm{x}$ & & & & \\
\hline 64 & 26,23 & Triphenylene & $\mathrm{x}$ & $\mathrm{x}$ & $\mathrm{x}$ & $\mathrm{X}$ & $\mathrm{x}$ & & & & \\
\hline 65 & 26,42 & Docosanoic acid, methyl ester & & & & & & $\mathrm{X}$ & & & \\
\hline 66 & 27,44 & Tetracosanoic acid, methyl ester & & & & & & $\mathrm{X}$ & & & \\
\hline 67 & 27,95 & Benzo[k]fluoranthene & $\mathrm{x}$ & $\mathrm{x}$ & $\mathrm{x}$ & $\mathrm{X}$ & $\mathrm{x}$ & & & & \\
\hline 68 & 28,32 & Benzo[b]fluoranthene & $\mathrm{x}$ & $\mathrm{x}$ & $\mathrm{x}$ & $\mathrm{X}$ & $\mathrm{x}$ & & & & \\
\hline 69 & 28,46 & Hexacosanoic acid, methyl ester & & & & & & $\mathrm{X}$ & & & \\
\hline
\end{tabular}

